\title{
El eterno retorno de Marquetalia: sobre el mito fundacional de las Farc-EP'
}

\author{
The eternal return of Marquetalia: on the founding \\ myth of the FARC-EP
}

Giohanny Olave²

\section{Resumen}

El objetivo de este texto es revisar la influencia del relato del origen de la guerrilla de las Farc-EP en el carácter prolongado del conflicto armado con las Fuerzas Armadas estatales, además de profundizar en la configuración de lo que se ha venido denominando el mito fundacional de Marquetalia, por parte de la literatura disponible sobre el grupo insurgente. Metodológicamente, se realiza un análisis documental desde la perspectiva del análisis del discurso con enfoque sociocognitivo. En los resultados se relevan los puntos del relato de origen que perviven en los documentos actuales y, por extensión, en el marco ideológico fariano, además de aproximarse a la construcción de la subjetividad del militante, a través de la definición del ideal heroico del guerrillero. Se concluye que el mito fundacional condensa lo histórico, lo emotivo y lo sociocognitivo, elevando a símbolo el relato del origen y volviendo a él cada vez que se requiere reforzar, definir o regular la moral del guerrillero.

\section{Palabras clave:}

Conflicto armado colombiano, insurgencia, moral guerrillera, mito fundacional.

\section{Abstract}

The aim of this paper is to review the influence of the story of the origin of the Farc-EP in the ongoing armed conflict with the state military forces, deepening in shaping what has been called the "founding myth of Marquetalia" from the available literature on the insurgent group. Methodologically, a documentary analysis was done from the perspective of discourse analysis with a socio-cognitive approach. The results highlighted the components of the mythic tale that survive in the current documents and, by extension, the ideological Fariano framework, as well as it approaches the construction of the subjectivity of the militant, through the definition of the ideal heroic guerrilla. We conclude that the founding myth condenses the historical, emotional and sociocognitive, elevating the story of the origin to the symbol and returning to it whenever it is required to strengthen, define or regulate the guerrilla morale.

\section{Keywords:}

Colombian armed conflict, insurgency, guerrilla moral, founding myth

Artículo recibido el 20 de abril de 2012 y aprobado el 8 de febrero de 2013

1 El texto es un producto de una tesis doctoral en curso, titulada "La construcción retórica del conflicto armado colombiano", dirigida por la Dra. Elvira Narvaja de Arnoux, en la Universidad de Buenos Aires.

2 Universidad de Buenos Aires, Buenos Aires, Argentina. Correo electrónico: olavearias@gmail.com 
Es necesario laicizar radicalmente nuestros saberes y nuestras prácticas políticas a través de una crítica teórico-práctica de lo sagrado, develadora de la pervivencia de lo religioso en lo político, de los dispositivos a través de los cuales el mito aún aprisiona nuestras razones y nuestra pasiones, consume nuestras mejores energías, esteriliza nuestra creatividad.

H. Tarcus (1998, p. 31)

En mayo de 2013 se cumplirán 49 años de levantamiento en armas por parte de las Fuerzas Armadas Revolucionarias de Colombia, Ejército del Pueblo (Farc-EP). En la actualidad, este grupo insurgente cuenta aproximadamente con 8000 a 10000 guerrilleros 3 , 69 frentes y presencia importante en el territorio rural colombiano, desde donde operan con una estructura política y militar consolidada y reconocida por las fuerzas armadas legales del Estado, quienes confrontan a los guerrilleros regularmente, en el esquema de contrainsurgencia en guerra de guerrillas.

Uno de los interrogantes más complejos que genera el conflicto armado en Colombia es precisamente su carácter prolongado, único en el continente y uno de los tres más antiguos del mundo (junto a los conflictos étnico-religiosos en Birmania y en el territorio Palestino-Israelí, ambos vigentes desde 1948). Por supuesto, entendemos que se trata de una prolongación dinámica, es decir, no se niegan los procesos de transformación tanto de los actores como del conflicto mismo, pero al igual que el mítico dios Proteo, cambia incansablemente el aspecto de su cuerpo conservando casi inamovibles las cuestiones de fondo más esenciales. El objetivo de este texto es revisar la influencia del relato del origen fariano en tal carácter prolongado y profundizar en la configuración de lo que se ha venido denominado

3 No existe un número reconocido por parte de las Farc-Ep, por razones estratégicas. Este dato lo calculan corporaciones como Nuevo Arcoiris (2012) y Cinep (2012), organizaciones no gubernamentales que trabajan sobre el conflicto armado en Colombia. el mito fundacional de Marquetalia, por parte de la literatura disponible sobre las Farc-Ep4.

Primero se realizará un acercamiento teórico al concepto de mito fundacional; luego se analizará el relato de los orígenes de las Farc-Ep, centrado en los hechos de Marquetalia, y se recogerá el análisis en la caracterización del mito fundacional como semillero de los valores heroicos que definirán la figura del guerrillero en la organización; finalmente, se concluirá con una valoración final del mito de Marquetalia en relación con las condiciones actuales del conflicto armado colombiano.

\section{El mito fundacional}

Campbell (1991) atribuye una función sociológica a los mitos, al anotar que ellos apoyan y validan ciertos órdenes sociales al interior de las comunidades. Tales órdenes no solo regulan el comportamiento de los sujetos, sino también contribuyen a la configuración de identidades colectivas, es decir, son un factor de cohesión y de continuidad. La fuerza del mito fundacional o el relato mítico sobre el origen de los grupos, reside en ese relato cohesionador, que le provee a la colectividad ya no la búsqueda de un sentido, sino su encuentro y experiencia viva. ¿De qué se trata tal experiencia? De cómo los sujetos asumen un horizonte colectivo que se valida por residir en el origen y, al mismo tiempo, legitima la continuidad el orden que establece. En esta medida, hay que decir también que se trata de una experiencia de orden deóntico, con un claro carácter coercitivo basado en la moral que construye para sus miembros.

El mito fundacional explica el origen, la posición y la intersubjetividad de los actores. Ante todo, es una narración verosímil del pasado, y no necesariamente verdadera en el sentido estricto historiográfico. La verosimilitud de esta escritura o de esta redescripción, desde la perspectiva de Rorty (1997),

4 La literatura sobre las Farc-Ep es abundante; asimismo, existe acceso a sus documentos internos oficiales a través de páginas web y blogs de la organización. En este texto se ha realizado un recorte de ambos corpus atendiendo a la referencia (directa o indirecta) del mito fundacional, y se han seleccionado los más representativos, para evitar reiteraciones innecesarias. 
no se refiere al ajuste de los hechos a un conjunto de leyes externas de funcionamiento, sino a una lógica interna donde los mecanismos iniciáticos tienen la capacidad de reproducirse en el tiempo. A partir de esa lógica interna se erige una ideología secular y una teoría fundacional presentada y asumida como racional, científica, estatutaria y programática (Tarcus, 1998, p. 27).

Como toda narración, el mito fundacional define a unos actores como protagonistas y a otros como antagonistas; los primeros, por supuesto, son quienes escriben la historia, fundan, forjan, luchan, se sacrifican y obtienen lo deseado, siempre relacionado con lo justo. Toda creación emerge de un conjunto de condiciones que anteceden al mito en una lógica causal; el mito fundacional llena un vacío anterior o se opone al caos precedente instaurando un orden, en este caso, un ordenamiento de las relaciones de poder entre los actores. Al respecto, Ferro y Uribe (2002, p. 18) advierten que "los grupos insurgentes no operan necesariamente bajo la lógica del comportamiento-respuesta y por tanto no son solo una respuesta a la violencia estructural o institucional", es decir, no surgen espontáneamente a partir de una estructura sociopolítica particular en un momento histórico, sino que anclan su origen en la multiplicidad de factores diacrónicos y sincrónicos que conforman la percepción de un estado de cosas que urge ser transformado.

Para Legname (2002), "no es la historia lo que cuenta en la formación del mito, sino la escritura de la historia", es decir, la redescripción y definición de las situaciones que dice de la manera en que los actores la han hecho propia; interpretaciones móviles cuya "enunciación y escritura se adecua a los intereses de los distintos sectores en pugna en el juego del poder". La dialéctica entre transparencia y opacidad, movilidad y permanencia, flexibilidad y estabilidad al interior de los mitos fundacionales, precisamente por constituir un carácter contradictorio de su funcionamiento, revela lo que ellos comparten con la naturaleza social del hombre, en continuo tránsito entre los sentidos individuales y colectivos que experimenta el sujeto social. Desde esta perspectiva, enfocarlos puede ayudar a entender el origen de las convicciones que mantienen unidos a los miembros de un grupo:

La fidelidad al principio fundacional es una de las causas que explican el mantenimiento de una organización en el tiempo: Las opciones políticas cruciales puestas en práctica por los padres fundadores, las modalidades de los primeros conflictos por el control de la organización y la manera en que esta se consolida, dejarán una impronta indeleble (Panebianco, 1995, p. 17, citado por Ferro y Uribe, 2002, p. 33).

La aproximación a esa impronta es el objetivo del análisis del relato de Marquetalia como mito fundacional de las Farc-Ep. Previo al análisis, expondremos el marco histórico dentro del cual se inscribe dicho relato y la situación sociopolítica que precedió a los hechos de mayo de 1964.

\section{Los precedentes}

Existe acuerdo entre los historiadores de la realidad colombiana en definir el núcleo duro del conflicto armado interno como de carácter agrario, cuyos primeros levantamientos se originan durante los años veinte y treinta, por las deficientes condiciones de trabajo en las haciendas $y$, por tanto, la brecha social entre terratenientes $y$ campesinos; disputas en torno a la propiedad legal de la tierra; y la relación de los propietarios con las comunidades indígenas, quienes reclamaban también su propiedad tras sucesivas ocupaciones y expropiaciones. En principio, una especie de agrarismo revolucionario, basa su protesta en la creación de ligas y sindicatos (Pizarro-Leongómez, 1989).

Hay un punto de quiebre en la historia de estas protestas contra el sistema político de la época, ubicado en el periodo denominado La Violencia (1948-1964), cuya fecha inicial refiere al asesinato de Jorge Eliécer Gaitán, caudillo liberal candidato a las elecciones presidenciales, magnicidio atribuido al partido político de extrema derecha 
(conservadores), y cuya fecha final coincide con el ataque militar a la región de Marquetalia5:

La Violencia duró cerca de dieciséis años (19481964) y se destacó por su magnitud, su cariz fratricida y por la impunidad que rodeó los actos atroces que se cometieron durante esos años. Como corolario dejó una enorme cantidad de hombres muertos, mujeres violadas y niños huérfanos. Fue una confrontación que, aunque permitió que las tierras cambiaran de manos mediante la expulsión de sus aterrorizados dueños, en lo fundamental no alteró la estructura agraria que venía prevaleciendo, ni la distribución general de la riqueza, ni las condiciones de la dominación política (Uribe-Calderón, 2007).

El enfrentamiento, legendariamente sangriento ${ }^{6}$, entre liberales y conservadores ha hecho perder de vista el núcleo agrario de la lucha por la tierra, nublado por el relato de sectarismos y retaliaciones entre los partidos políticos; Hobsbawm (1968, p. 268) define este periodo como años de anarquía donde el hambre de tierras de "una clase media rural en ascenso se valió del ejercicio de la violencia para adquirir riqueza y poderío, lo que no hubiera podido adquirir por otros medios debido a la naturaleza feudal de la sociedad rural". La tensión entre terratenientes y campesinado, unos y otros adscritos de manera polarizada al bipartidismo de la época, origina el levantamiento en armas de ambos sectores, invocando la defensa personal y de la propiedad. Para Uribe-Calderón (2007, p.78):

Lo que confluyó alrededor de estos dirigentes campesinos antecesores de las Farc fue una tradición de lucha agraria, una marcada antipatía hacia los partidos tradicionales y un sentimiento de injusticia acumulado a lo largo de varios años de infructuosa lucha por la tierra.

5 Otros autores ubican el final de La Violencia en el año 1953, con el golpe de Estado del general Gustavo Rojas Pinilla.

6 Existe una extensa literatura de la violencia en Colombia, desde reconstruc ciones históricas de actores ligados a uno u otro partido, hasta narrativas novelizadas del conflicto, todas obras que confluyen en el desangre de la población colombiana, calculado entre cien mil y doscientos mil muertos en 16 años (Hobsbawm, 1968, p. 264).
Con el Partido Conservador a la cabeza del poder presidencial, las Fuerzas Armadas legales y otros grupos paramilitares persiguieron a los campesinos insurrectos, quienes conformaron grupos nómadas que se desplazaban por varias regiones del país (especialmente por el Tolima, suroccidente andino), entre 1949 y 1950: "La columna estaba integrada por cerca de doscientos campesinos armados que iban acompañados por sus familias. Ese desplazamiento es narrado por los insurgentes en términos épicos, lo cual lo convierte en parte del mito fundacional de las Farc" (Uribe-Calderón, 2007). En 1949, la dirección del Partido Comunista Colombiano ${ }^{7}$ hizo un llamado a organizar la autodefensa en todas las regiones amenazadas por ataques reaccionarios:

La autodefensa, de modo general, es caracterizada por sus promotores comunistas como una forma de defender los intereses del campesinado, para la lucha por la preservación de la paz y la normalidad para trabajar y producir en un ambiente pacífico. La composición social es heterogénea, pues aun cuando la mayor parte la integran campesinos pequeños y medianos, en ocasiones participan campesinos ricos (Pizarro-Leongómez, 1989).

En principio, las guerrillas de inspiración liberal y las comunistas establecieron enclaves compartidos en regiones del suroccidente y del oriente colombiano; esta unidad inicial entró en crisis a raíz de los fundamentos políticos que sostenían a cada grupo y que divergían, sobre todo, en la dirección de partidos y en el rol de la lucha armada como método político; para Pizarro-Leongómez (1989, p.9), "la guerra entre los limpios (o liberales limpios) y los comunes (o liberales sucios), tuvo ribetes trágicos. Más eficaz que la acción oficial resultó esta guerra interna que debilitó seriamente a ambas agrupaciones y que tuvo una duración de veintidós meses".

7 “Las primeras manifestaciones de la izquierda en Colombia se presentan hacia comienzos del siglo XX con la formación de sindicatos y de algunos grupos socialistas. También, hacia finales de la primera década del siglo, entre 1915 y 1920, llegan al país algunos anarquistas europeos que ayudan a conformar grupos de reivindicación agraria en varias zonas del país, especialmente en el departamento de Córdoba, cerca de la frontera con Panamá" (Salazar, 2005). El Partido Socialista Revolucionario (PSR) se funda en 1924, para julio de 1930 cambia el nombre por Partido Comunista Colombiano, dando origen formal a un partido político de izquierda en Colombia (Pataquiva, 2009). 
En 1953, el general Gustavo Rojas Pinilla toma el poder a través de un golpe de Estado. La promesa de pacificar el conflicto bipartidista y un programa de amnistía a las guerrillas liberales y comunistas fueron las principales razones del Congreso $\mathrm{Na}$ cional y la Asamblea Nacional Constituyente, que terminaron avalando la toma del poder por parte del militar. No todos los núcleos insurgentes guerrilleros se acogieron al armisticio de Rojas Pinilla8; los grupos comunistas que se negaron a deponer las armas acogieron las nuevas instrucciones del partido sobre replegarse en el formato de guerrillas móviles; sin embargo

La dinámica autodefensa/guerrilla/autodefensa no implica, como lo han mostrado algunos analistas, que la guerrilla móvil surja automáticamente del movimiento agrario y que una vez cambien las circunstancias, nuevamente se transforma en autodefensa. Solo en muy pocos casos la dinámica se presentó de esa manera. El ciclo se define, más que en relación con procesos armados en particular, con respecto a la política global del Partido Comunista en cada periodo. Este partido estimuló el desarrollo de una u otra modalidad de resistencia en concordancia con la coyuntura política de represión oficial o de tregua pactada (Pizarro-Leongómez, 1989).

A partir de 1957, con el acuerdo bipartidista conocido como el Frente Nacional (repartición del poder público entre liberales y conservadores en periodos alternados), la Doctrina de Seguridad Nacional que fue impulsada por Estados Unidos en todo el continente, alimentó un fuerte anticomunismo contra las guerrillas de izquierda, en el marco de la Guerra Fría.

8 Durante el proceso de amnistía de Rojas hubo todo tipo de rendiciones. Algunas fueron incondicionales con exigencias al gobierno hechas a posteriori; otras plantearon exigencias previas a la entrega y propuestas de desmovilización sin entrega, como la de Juan de la Cruz Varela y sus guerrillas del Sumapaz en Cundinamarca. Los comunistas continuaron en armas y se desplazaron hacia algunas zonas selváticas de la cordillera oriental para conformar lo que el dirigente conservador Álvaro Gómez llamó en su momento repúblicas independientes y los grupos insurgentes zonas liberadas, es decir, territorios que establecieron una política de desobediencia civil frente al Estado (Uribe-Calderón, 2007).
El poderoso influjo de la Revolución cubana y el carácter excluyente del Frente Nacional son dos factores fundamentales para entender los estallidos de violencia que aparecieron con mayor fuerza después de un breve periodo de pacificación. En este, las guerrillas que no depusieron las armas se extendieron a lo largo de la cordillera oriental en una suerte de colonización armada, presentándose a sí mismas como un "vehículo de expresión de los reclamos de sectores campesinos que quedaron excluidos del acuerdo bipartidista” (Uribe-Calderón, 2007).

El precedente de este largo periodo de insurgencia campesina es reconocido por las Farc-Ep y reclamado como deuda social del Estado. Las primeras guerrillas comunistas y la posterior conformación de la guerrilla fariana comparten esa definición como movimiento antiestatal y antioligárquico, que reclamaron el abandono del régimen político en torno a la distribución inequitativa de la riqueza y de la tierra.

Para los primeros años de la década de 1960, los enfrentamientos entre la fuerza pública y las guerrillas comunistas generaban un clima de violencia e inestabilidad sociopolítica permanente. Las zonas donde se habían asentado las guerrillas, las llamadas repúblicas independientes, habían perdido control casi total del Estado, por lo cual la política contrainsurgente del presidente de turno (Guillermo León Valencia, 1962-1966) se enfocó en su exterminio. Marquetalia, una de las repúblicas, ubicada en el corregimiento de Gaitania (municipio de Planadas), suroccidente del departamento del Tolima, fue uno de los objetivos militares a través de la llamada Operación Marquetalia, cuyo ataque principal ocurrió en mayo de 1964.

\section{Análisis del relato de Marquetalia}

Elevado a símbolo, el ataque y resistencia en Marquetalia le sirve a las Farc-Ep, más que como un referente histórico, como una condensación o síntesis de las relaciones de poder entre el Estado y la insurgencia, es decir, establece una figura de representación total del todo a partir del recorte de una parte. La simbolización deviene también 
en idealización de Marquetalia como un mundo rural posible, perdido y arrebatado por la violencia estatal indiscriminada: "Encarna el deseo que tenían los colonos de la frontera, y que quizás aún acarician los combatientes históricos de las Farc, de un mundo ausente de terratenientes y conformado por pequeños propietarios independientes" (UribeCalderón, 2007).

Presentado como simiente de la lucha guerrillera, el ataque a Marquetalia es el ataque del victimario represor contra el campesinado víctima de la Fuerza Pública, y al mismo tiempo, se presenta como justificación directa de la continuidad del levantamiento en armas, que ya venía operando desde la conformación de las repúblicas independientes o zonas liberadas 9 . La referencia a la intervención estadounidense establece la definición del enemigo, y desde el principio promulgará la doctrina antiimperialista: "Es necesario precisar cuál es nuestro enemigo principal para dirigir el filo de nuestro lucha contra él. El imperialismo yanqui es no solamente nuestro enemigo, sino el enemigo de todos los pueblos de la tierra" (Arenas, 1972), discurso que se hereda hasta la actualidad en la comandancia de Timoleón Jiménez (Farc-EP, octubre 1 de 2012): "La oligarquía dominante en Colombia, apoyada sólidamente por los gobiernos de los Estados Unidos, lleva ya casi 50 años apostándole al exterminio de las guerrillas". La doctrina del enemigo externo sustentará la contraofensiva del grupo guerrillero desde sus orígenes, adscribiéndose a la lucha contra el capitalismo y la dominación extranjera:

El 27 de mayo de 1964, bajo la presidencia del conservador Guillermo León Valencia (19621966), las Fuerzas Militares desatan la operación Marquetalia, bajo los lineamientos generales del

9 “La 'República de Marquetalia' será el resultado de una lenta convergencia entre los destacamentos comunistas de Rionegro, La Herrera y Planadas, con el refuerzo de la gente armada de Miraflores. Pero el catalizador que, en última instancia, definirá, más que los hombres, cuál será el punto de reunión de esas organizaciones subversivas, es la geografía, ya que el centro de este territorio de la cordillera central es bastante particular: se trata de una inmensa montaña, o más bien de un volcán, que se eleva hasta los 5750 metros, coronado con nieves perpetuas, más conocido bajo el nombre de nevado del Huila" (Mackenzie, 2007, p. 192).
Plan Laso, Latin American Security Operation, diseñado por el Pentágono estadounidense y la Embajada Norteamericana, para que de una vez por todas quede claro de dónde partieron en última instancia las órdenes de la operación militar. Comienza la operación militar contra Marquetalia, el más grande operativo militar realizado hasta el momento en Colombia. Es el comienzo de nuevo de la resistencia armada en Colombia. Por meses se combate en la montaña y en la selva y el pequeño y valeroso grupo de 48 hombres se convierte en guerrilla móvil, dirigidos por Manuel Marulanda Vélez, un maestro de la guerra popular guerrillera [...]. El Ejército toma simbólicamente la región de Marquetalia, pero militarmente le fue imposible, a pesar de su nueva concepción contraguerrillera, acabar con la simiente de la lucha que había emergido en esas tierras. Esa simiente es la raíz de las Farc-Ep. Marquetalia es pues, el símbolo de esta etapa prolongada del movimiento guerrillero moderno de nuestra patria (Farc-Ep, 1998).

El Ejército colombiano siempre ha desmentido que la Operación Marquetalia haya sido parte del Latin American Security Operation o Plan Laso, y ha presentado la operación como Plan Lazo, ideada y organizada internamente ${ }^{10}$. La injerencia norteamericana es la piedra de toque en este punto y ha generado la crítica permanente de las Farc-Ep sobre el respeto a la soberanía e independencia nacional por parte del Estado; las Farc-Ep no dejan de denunciar programas específicos, como el Plan Colombia (vigente desde 1999), señalándolos como "proyectos de intervención militar de Estados Unidos en nuestro territorio" (Farc-EP, 2001, p. 61). Así lo presenta el relato:

El Plan Laso, fiel ejecución de las fuerzas militares colombianas a las órdenes emanadas del Pentágo-

10 Pizarro Leongómez (2004a) referencia los estudios de Dennis Rompe sobre la existencia efectiva de un Plan Laso para América Latina, diseñado en Washington en el marco de la política de contrainsurgencia posrrevolución cubana, que impulsó el gobierno de John F. Kennedy con la Alianza para el Progreso. Para el autor, es posible que este proyecto global se haya españolizado bajo el nombre de Lazo en la también llamada Operación Soberanía contra Marquetalia. Otros autores, como Mackenzie (2007) atribuyen el cambio de laso a lazo a una estrategia de la propaganda opositora para desacreditar el control del territorio por parte de las Fuerzas Armadas legales. 
no, desembocó en los ataques a las zonas agrarias de Marquetalia, El Pato, Riochiquito y Guayabero [...]. ¡Qué estrellada tan grande la de la oligarquía colombiana y el imperialismo! Si se metieron fue con los fundadores inmortales Manuel Marulanda Vélez, Jacobo Arenas, Hernando González Acosta, Isaías Pardo, Isauro Yosa, Rigoberto Lozada, Judith Grisales, Myriam Narváez, y cuatro decenas más de líderes y trabajadores del agro, que concentraban en sí toda la energía y el valor de un pueblo herido y dispuesto a luchar hasta el fin por sus derechos (p. 41).

La inmortalidad de los fundadores es un aspecto clave del mito fundacional: ello encarna en la figura de los marquetalianos el modelo del guerrillero: una moral de conducta, caracterizada por la tenacidad, la rebeldía, la persistencia y el origen campesino; se trata aquí de figuras ejemplarizantes en la memoria discursiva del grupo insurgente, invocadas ya no para reivindicarlas, sino para moralizar a los combatientes y, con particular intensidad, a aquellos caídos en desgracia: "eres símbolo de nuestros prisioneros, aquellos que reciben el maltrato y el odio del sistema, por el solo hecho de ser farianos, de significar la continuidad del ejemplo de Manuel [Marulanda] y de Jacobo [Arenas]" (Farc-EP, octubre 1 de 2012).

También estos fundadores se presentan como portavoces de la población rural colombiana, con lo cual reconocen los precedentes del socialismo agrario temprano. En la misma referencia al Plan Laso, Arenas ${ }^{11}$ (1972, p.10) escribe:

Este monstruoso plan pretende ser justificado por el gobierno y los jefes militares con el argumento de destruir "focos de bandoleros", colocando a un movimiento de trabajadores agrícolas en el mismo plano de los grupos de asesinos organizados en años anteriores por el oficialismo liberal y algunos círculos conservadores, con el objetivo de destruir las organizaciones de los campesinos.

Las Farc-Ep siempre buscaron desprenderse de los demás grupos insurgentes que surgieron a raíz de las disputas bipartidistas. Los denominados

11 Jacobo Arenas, alias de Luis Alberto Morantes Jaimes, líder ideológico y fundador de las Farc, muerto el 15 de agosto de 1990. bandoleros hicieron leyenda en la literatura sobre el periodo de La Violencia en Colombia, pero se presentaron más como bandas de reacción violenta que como grupos con orientación política. Precisamente, esta aspiración política inicial explica la filiación originaria de las guerrillas con el Partido Comunista Colombiano:

Nosotros hemos llegado a todas las partes donde había puertas para golpear, en procura de auxilio para evitar que una cruzada anticomunista, que es una cruzada antipatriótica contra nuestro pueblo, nos llegara, y con nosotros a todo nuestro pueblo, a una lucha larga y sangrienta. Nosotros somos revolucionarios que luchamos por un cambio de régimen. Pero queríamos y luchábamos por ese cambio usando la vía menos dolorosa para nuestro pueblo: la vía pacífica, la vía de la lucha democrática de las masas, las vías legales que la Constitución de Colombia señala. Esa vía nos fue cerrada violentamente y como somos revolucionarios que de una u otra manera jugaremos el papel histórico que nos corresponde, obligados por las circunstancias arriba anotadas, nos tocó buscar la otra vía: la vía revolucionaria armada para la lucha por el poder (Arenas, 1972, p.98).

La reivindicación del guerrillero como revolucionario, bajo el cariz político del comunismo, se articula con la figura del campesino pacífico que es obligado a tomar las armas para lograr ser escuchado. El campesino revolucionario es presentado como el homólogo del proletario de las urbes, dirigido por el idéntico llamado de la historia, es decir, protagonista de la transformación social como imperativo sociohistórico.

En distintas ocasiones, Marulanda planteó este esquema de rebelión armada como el sucedáneo causal de las primeras protestas pacíficas de líderes sindicalistas, oprimidas por la violencia del Estado. El alzamiento en armas se presenta, pues, como una vía a la cual se llegó de manera obligada, reconociendo y augurando desde sus orígenes una lucha larga y sangrienta. Para Pizarro-Leongómez (2004a, p.4), en este carácter reactivo se sostiene el mito fundacional: 
Según este mito, las Farc no surgieron por iniciativa propia, sino como resultado de una agresión externa. El movimiento guerrillero incipiente no habría sido quien le declaró la guerra al Estado, sino, por el contrario, fue el Estado quien le declaró la guerra a las organizaciones agrarias comunistas, las cuales se vieron obligadas a defender su vida mediante las armas.

Desde el mito de origen, las Farc-Ep han cumplido también un rol de denuncia de los excesos de la fuerza pública frente a la sociedad colombiana. En esa suerte de función veedora, los reclamos se han mantenido más o menos estables con respecto a la legitimación de una violencia estatal oculta tras las políticas contrainsurgentes:

Las Fuerzas Armadas lograron incendiar 100 casas y se apoderaron de 100 fincas. Ocuparon los terrenos abiertos de la región, devoraron 100 000 aves de corral y 10000 cabezas de ganado; encarcelaron 2000 campesinos; han asesinado más de 200; han torturado decenas de personas. El daño causado a la región se eleva a unos 20 millones de pesos. Lograron matar en combate al guerrillero Luis Salgado; con fuego aéreo a Georgina de Ortiz, y con bombas explosivas a dieciocho niños refugiados en la selva. La “operación” hizo crecer a Marquetalia, provocó el más formidable movimiento nacional de solidaridad e inauguró una nueva etapa de luchas revolucionarias en Colombia. El movimiento agrario de Marquetalia se transformó en movimiento guerrillero con un programa revolucionario y es hoy muchísimo más fuerte y superior de lo que era antes de la agresión (Arenas, 1972, p.28).

La tortura, el saqueo y la violencia indiscriminada contra la población civil configuran una representación de la toma de Marquetalia que sobrevivirá en los posteriores reclamos de las Farc-Ep, extrapolada a los demás episodios de confrontación bélica en las zonas campesinas del país. Así lo reiteraba Marulanda, sin grandes diferencias, en los discursos anuales que conmemoraban el nacimiento del grupo guerrillero, y en el histórico discurso leído por uno de sus comandantes al inaugurar los fallidos diálogos de paz con el presidente Pastrana, en enero de 1999:
El comandante de la guerrilla mandó un texto escrito que fue leído durante la ceremonia de instalación de la mesa. En éste, Marulanda le reclama al gobierno las vacas, cerdos y gallinas que los soldados se robaron durante la operación militar contra Marquetalia. El reclamo puso en evidencia el hondo sentimiento de pérdida que se había enconado con el paso de los años, relacionado con la identidad de Marulanda como campesino despojado (UribeCalderón, 2007, p.200).

Del mismo lado, el relato épico de la colonización armada tiene un referente directo en la Gran Marcha, o el viaje al interior de la China que siguieron las tropas del Ejército Rojo (Partido Comunista Chino) huyendo del Ejército de la República (1934-1935):

Los días pasan. Nosotros siempre estamos en movimiento. La tropa enemiga avanza, los guerrilleros golpean aquí y allá y vamos al ritmo de la marcha guerrillera. Llevo en mi mochila los utensilios de mi labor. Al lado de las trochas aparecen de vez en cuando chozas (...). Vamos instalando nuestras tiendas en un lugar y al día siguiente en otro distinto hasta hundirnos en las profundidades de la selva (Arenas, 1972, p.21).

El simbolismo de la Gran Marcha, dada su importancia en la historia del comunismo chino, es emparentado en el relato épico particularmente por tres puntos en común: el primero es el establecimiento de una zona liberada, bajo control comunista en un área montañosa, cuyo nombre fue "República soviética de China”, en la provincia sureña de Jiangxi; el segundo es la figura de Mao Zedong como uno de los líderes de la Gran Marcha y posterior figura fuerte del proyecto comunista; y el tercero es el carácter campesino de los revolucionarios que lograron el ascenso del comunismo en China:

El 22 de septiembre las familias salieron hacia otro poblado de caletas, remontando la cordillera. Los accidentes del terreno no permiten llevar animales de carga, ni ganado. Ahora es la misma gente la que debe cargar como las bestias. Suben las cuestas cargando lo que pueden resistir sobre las espaldas. Las piernas se tensan y parecen ceder a cada momento bajo el peso de los fardos llenos hasta los bordes. Encima de los fardos van niños, cerdos, lechones o gallinas (Arenas, 1972, p.93). 
La Gran Marcha es también la historia de las peregrinaciones dolientes, del sacrificio colectivo y de la promesa ulterior; un mito fundacional foráneo al que se acude para contar la historia que coincide con la colonización armada, que precede al asentamiento y posterior huida de Marquetalia. En el mismo, el adversario es presentado como un otro-bárbaro, despojado de humanidad y transgresor de las leyes de la guerra; una ilegitimidad que al ser remarcada en el otro llega a justificar las acciones del primero, en legítima defensa: "Vienen las torturas. Ya no conducen a la gente presa sino que llevan solamente las cabezas para su identificación en los puestos militares" (Arenas, 1972, p.54).

La presencia de lo pathémico (lo dirigido a mover las emociones) en el discurso político, en general, y en el discurso insurgente, en particular, reviste al relato de la fuerza lírica del mito; la clave es la figura del campesino compenetrado con la naturaleza, equilibrio en el que irrumpe el hombre de ciudad con la fuerza pública. La clara tensión entre lo rural y lo urbano forma parte esencial del conflicto armado interno en Colombia: "Así eran siempre las noches de insomnio. Sueños, fiebre alta, mosquitos insoportables. Se escuchaban ruidos de animales selváticos, quejidos humanos, cantar de fuentes, monótona lluvia... una gotera helada sobre el cuerpo de un niño que también soñaba" (Arenas, 1972).

Los 16000 soldados contra los 48 guerrilleros es, quizás, la figura más poderosa en la configuración de una guerra asimétrica donde los débiles están llamados a vencer, como en el mito de David y Goliat (así lo presentaba el anterior jefe Alfonso Cano, en entrevista de 2011), a pesar de la desigualdad de condiciones:

Contra el núcleo revolucionario de Marquetalia se emplearían a fondo 16000 hombres del ejército. Fuerzas combinadas de infantería, artillería, aviación para bombardeos y aerotransporte iniciarían la agresión. Se emplearía en todo su rigor la táctica del cerco y el bloqueo. Si se producía por parte de los campesinos alguna manifestación de resistencia, serían lanzadas bacterias contra la población. (Arenas, 1972, p.8).
Para Mackenzie (2007), el relato de los 48 hombres que escaparon a los 16000 soldados "será una variante colombiana de la leyenda fabricada en 1945 por el Partido Comunista Francés sobre 'el partido de los 75.000 fusilados', tan apreciada por Maurice Thorez, el desertor de 1940, amnistiado tras la liberación por el general De Gaulle" (p. 219).

La intervención de Estados Unidos en Marquetalia es denunciada también con la acusación del uso de napalm y el despliegue de armas bacteriológicas, lo cual ha sido desmentido en varias ocasiones por los actores oficiales:

No se arremetió contra Marquetalia con los 16000 hombres de la leyenda negra. Se emplearon tres batallones (1500 hombres) que ocuparon las zonas circunvecinas para sustraerlas del influjo del patriarca, mientras una fracción de infantería avanzó por el cañón del río Atá, atrayendo a Tirofijo al inexpugnable sitio de las Juntas, en tanto el teniente coronel Joaquín Matallana descendía en audaz asalto desde helicópteros en vuelo para apoderarse del caserío sin un tiro. Me correspondió como oficial de operaciones (E-3) del Ejército proyectar el plan Meteoro. Puedo afirmar, por lo tanto, que no se produjeron ni los atroces bombardeos, ni la política de tierra arrasada, ni el saqueo agropecuario del que habló Marulanda en San Vicente del Caguán. Mucho menos bombas bacteriológicas lanzadas por pilotos gringos, que jamás han actuado en operaciones militares en Colombia (Valencia, 1999, citado por Alape, 1985, p.236).

En contraste con el relato fariano de Marquetalia: - Las bacterias, hermano. Me están tragando. Tengo fiebre, dame una pasta de Plaquinol. Le respondo, también en voz baja, que no tenga ningún temor, pues está vacunado contra todo eso que han lanzado los gringos desde los aviones [...] "Ese mismo día amanecieron varios compañeros y compañeras con la viruela negra". Por parte del enemigo se abre entonces un paréntesis de expectativa, en espera de la acción de las bacterias [...] A las 9:55 del 15 de junio, dos cazas a reacción ametrallaron y lanzaron 20 bombas de alto poder sobre el caleterío donde se concentraba la mayoría de las familias, arriba del poblado, en la selva. 
Quince niños resultaron muertos por la acción de las bombas. Los adultos, hombres y mujeres, buscaron refugio en las cepas de los árboles y en cuevas previamente adaptadas para el caso. El bombardeo fue sorpresivo, lo cual impidió a los mayores poner a salvo a los niños [...] Es entonces cuando la fuerza aérea lanzó bombas napalm sobre las casas del poblado. Las casas fueron reducidas a cenizas pero la tropa no pudo penetrar al altiplano ese día. (Arenas, 1972, p.27).

La acusación de una guerra sucia inspirada por Estados Unidos, "en el seno de la cual los especialistas norteamericanos iban a poner en práctica sus experiencias de combate en Vietnam, Corea y Argelia" (Marulanda, 1973), es denunciada tempranamente por las Farc-Ep, primero contra los campesinos reaccionarios, y posteriormente contra el mismo grupo guerrillero, "en la nueva filosofía de la guerra irregular que practica típicos procedimientos fascistas" 12 .

El paso de un conjunto de motivos iniciales a una meta ideológica es producto de una lectura política de Marquetalia, cuyo funcionamiento interno evidencia la construcción de un sentido colectivo a partir de la desgracia, es decir, de un sentido mítico-heroico:

Queda claro, pues, que una guerrilla revolucionaria es indestructible cuando se guía por una línea política acertada y pone en práctica toda la riqueza de la táctica de la lucha guerrillera. Queda claro que otros grupos armados, en diversos lugares del país, pueden poner en jaque a las Fuerzas Armadas. Y queda claro también la importancia de la lucha armada dentro de la concepción general de la combinación de todas las formas de lucha del pueblo, para llegar al objetivo central de la

12 Otro relato publicado en la época por el Partido Comunista describe la escena de la siguiente forma: "[...] ha comenzado la resistencia. La lucha será larga y tenaz [...]. Necesitamos revitalizar la capacidad de lucha de los viejos guerrilleros que con su heroísmo han escrito el mejor trozo de historia auténticamente nacional [...]. No bastaron cerca de veinte mil hombres lanzados contra nosotros para someternos. Se vieron precisados a recurrir a la guerra bacteriológica. Aquí presenciaron el lanzamiento de las bacterias. Dicen que eran pequeños frascos de cristal que al chocar contra la tierra o los árboles se rompían y contaminaban las aguas y la selva" (Pizarro-Leongómez, 2004a, p.4). toma del poder. Esto no era muy evidente antes, pero ahora, con el ejemplo de Marquetalia, ha quedado perfectamente establecido en nuestro país. (Arenas, 1972, p.72).

Ferro y Uribe (2002) desprenden del carácter mítico-heroico la cohesión interna que explica la permanencia en el tiempo del objetivo político y la ideología inicial en torno a la lucha agraria:

Esos combatientes, con una visión de lucha campesina, le dieron al movimiento una ideología inicial que unificaron bajo la bandera de la lucha revolucionaria del Programa Agrario Nacional proclamado el 20 de julio de 1964 en la asamblea general de guerrilleros. A partir de ese día se decidió que la lucha no sería solo por la autodefensa, "nos convertiríamos en guerrilleros revolucionarios" (p. 34).

La lógica de una ética sacrificial (Carnovale, 2011), cuya adherencia y compromiso total con su idea, partico o causa, implica además de la disposición a dar la vida, participar en la conformación de una ética combatiente que impida toda capitulación, fue asumida por los primeros guerrilleros campesinos, acostumbrados al exigente trabajo en el campo y cansados del maltrato y las condiciones inequitativas en sus relaciones con los terratenientes. El relato del mito fundacional presenta el conjunto de sacrificios iniciales y las primeras marchas huyendo de las fuerzas represivas del Estado bajo un signo claramente positivo: el del mérito del hombre revolucionario como un hombre nuevo, entregado a la causa. Arenas (1985) exhorta a recordar los orígenes desde tal ética sacrificial en su reconstrucción histórica:

[...] cómo con 200 mil pesos libramos la lucha guerrillera de Marquetalia y la de Riochiquito [...]. En aquellos tiempos teníamos sentido proletario de la economía, del manejo razonado y consciente del dinero, sabíamos cuidar el dinero del movimiento, había grandes limitaciones en el gasto, se pensaba más en la guerra que en gastar el dinero sin ton ni son. Había poco dinero, pero había que salir adelante, y así lo hicimos. En esa época los guerrilleros no usaban botas sino tenis. A los pocos días había que ver esos tenis repujados de cabuya que herían los pies y hacían más 
dura la transhumancia de la guerrilla. La ropa era andrajosa y con remiendos. No había casi droga y durante un tiempo hubimos de comer sin sal. El dulce era limitado, y cuando llegaba qué fumar había fiesta. Con todo, hubo un núcleo de combatientes dispuesto a darlo todo por la Causa Revolucionaria y por eso Marquetalia se creció en la resistencia y sentó las bases políticas, militares y morales de lo que serían un poco más tarde las FARC (Arenas, 1985, p.40).

Se trata aquí de una "retórica exaltada de la guerra" (Vezzetti, 2009, p. 135), que llega a subvertir los hechos de la derrota (como lo fue la toma de Marquetalia) para presentarlos como sacrificios necesarios en la perspectiva de un proyecto superior a sus miembros, e inclusive, a sus mismos dirigentes.

El mito fundacional es capaz de extenderse en el tiempo y de reactualizarse en cada acción presente en la lucha armada, especialmente cuando se hacen más evidentes las relaciones asimétricas entre los actores en disputa. Tal vigencia en el imaginario de los guerrilleros, "ha permitido que la idea y la práctica de la resistencia se reproduzcan, lo que resulta fundamental cuando se trata de entender su cultura organizacional y su dinámica militar" (Uribe-Calderón, 2007):

La actitud de la gente de Marquetalia fue una actitud de dignidad, de asumir lo que está haciendo y no someterse a las condiciones del otro en una inferioridad de condiciones totales. Y ese gesto se extiende, porque los marquetalianos no son simplemente los que empezaron ahí, sino los que siguieron, los combatientes que se vinculan hoy [...]. La palabra resisitencia sintentiza todo, porque es armada, política e ideológica. Nosotros quéle venimos diciendo a la gente, hay que resistir, y si hay que hacer dos o tres Marquetalias, pues las haríamos, podemos hablar de una cultura fariana, la cultura de la resistencia, la cultura de la igualdad. Son valores que identifican a la organización (Ríos13, 1999, citado por Ferro y Uribe, 2002, p. 35).

13 Comandante Iván Ríos, alias de Manuel de Jesús Muñoz Ortiz, exjefe del Bloque Central de las Farc-Ep, abatido el 3 de marzo de 2008.
Como referente fundacional, Marquetalia también funciona como símbolo identitario, al conservar la línea de la lucha agraria y el predominio de lo rural en su ideología, programas, campos de acción y naturaleza de sus integrantes; para UribeCalderón (2007), este predominio puede explicar el aislamiento del grupo guerrillero con respecto a la población citadina, si bien hay que aclarar que no se trata de una ausencia total en las ciudades (prueba de ello es el funcionamiento de las milicias urbanas, el Movimiento Bolivariano y el Partido Comunista Colombiano Clandestino -PCCC-, células urbanas de cuyas cifras es difícil hacer una estimación).

El mito fundacional despliega su función pedagógica al instaurar una moral implícita en el relato del comportamiento de sus actores, y hacerla explícita en la caracterización del perfil guerrillero (como se verá más adelante):

Hay que tener presente la lección de Marquetalia (...): un pueblo honrado al que se le niegan soluciones y se le agrede para exterminarlo, termina convertido en una fuerza invencible alzada en armas (Arenas, 1985, p.56).

Esta lectura de Marquetalia coadyuva con la generación de un conjunto de certezas que construyen la convicción de los combatientes, sin la cual no es posible explicar la permanencia en armas del grupo guerrillero. Extrapolando el análisis de Carnovale (2011) sobre la guerrilla del Ejército de Revolución Popular (ERP), en la Argentina de los años setenta, es posible afirmar que también para las Farc-Ep, tales certezas giran alrededor de la percepción de la injusticia en el sistema social, que sustenta "una violencia inicial (y de ahí la legitimidad de la violencia contestataria), y la posibilidad cercana, cuando no inminente, de transformar el mundo a través de esa figura capaz de prometerlo todo: la revolución" (Carnovale, 2011, p. 251):

La verdad, hay que decirlo, lo que carece de sentido es estar asesinando y aterrorizando por la fuerza de las armas, a un pueblo que se organiza y reclama porque ese mismo Estado le niega la alimentación, la salud, el empleo, la vivienda, la educación, hasta la vida misma. Y esa ha sido la 
historia de nuestro país. No es el conflicto armado la causa del subdesarrollo. Son la falta de desarrollo $y$ la intolerancia las causas del conflicto. (Farc-Ep, 2001, pp. 73-75).

Finalmente, la redescripción de la realidad desde el mito fundacional pretende la universalidad de su versión escrita de la historia, toda vez que acude a un origen de ribetes ahistóricos, en suma, simbólicos. La instauración de una realidad desde la narrativa del origen les permite a los actores postular ya no solo una verdad, sino además una lógica de causas y efectos, exactamente inversa a la postulada por sus antagonistas.

\section{El legado del mito fundacional o el eterno retorno de Marquetalia}

Hasta aquí hemos examinado la capacidad que tiene el relato de Marquetalia, como mito fundacional, de desprenderse de su momento histórico y sobrevivir en el imaginario de la lucha armada al interior del grupo guerrillero; acordamos con Ferro y Uribe (2002), en este sentido: “Toda organización lleva sobre sí la huella de las peculiaridades que se dieron en su formación y de las decisiones políticas y administrativas adoptadas por sus fundadores" (p. 25).

Nos preguntamos ahora por los mecanismos a través de los cuales retorna el mito fundacional, utilizando lo que Vezzetti ha conceptualizado como la figura del hombre nuevo. Esta articula el relato del mito fundacional de las Farc-Ep con el modelo de guerrillero llamado a hacer la revolución; para Vezzetti (2009, p. 173), la aspiración de nuevos órdenes sociales implica la asunción de un nuevo sujeto, una nueva moral de conducta:

Convencidos que frente a nuestro pueblo debemos comportarnos y actuar como revolucionarios, como hombres y mujeres nuevos(as), con sencillez, para así contribuir a su incorporación a la lucha, los Comandantes de la Coordinadora Guerillera Simón Bolívar, reunidos en su Primera Cumbre "Jacobo Arenas", llaman a los combatientes bolivarianos a cumplir las siguientes normas de conducta [...]. (Farc-Ep, s.f.).
Estos nuevos valores son asumidos como normativas identitarias que definen al guerrillero desde una conducta opuesta a la del enemigo y diferenciadora de los demás grupos que se alzan en armas:

Nosotros no podemos confundirnos con los bandoleros, con los ladrones. Nosotros somos revolucionarios, y si no fuera porque lo necesitamos para que la revolución triunfe, tampoco tomaríamos los bienes del enemigo. Nosotros tenemos que estar más allá de las pequeñas cosas de comer, tenemos un objetivo estratégico que es la toma del poder. Por eso tenemos que estar más allá de las cosas pasajeras, de las cosas que mueven el interés personal. Esa es la filosofía de las clases enemigas y nosotros peleamos contra esa filosofía. También, entre nuestra actitud y la actitud del enemigo tiene que establecerse una diferencia clara y concluyente: nuestra actitud tiene que ser de amor al pueblo, de defensa del pueblo, mientras la de las fuerzas armadas oficiales es de odio al pueblo, de violencia, de robo y guerra al pueblo (Arenas, 1972, p.37).

La inscripción de un tercero (el pueblo, la comunidad) siempre inerme y vulnerado es la marca ideológica más representativa de la presentación heroica del actor, de su función colectiva en la misión revolucionaria. Las Farc-Ep se reivindican a sí mismas como portavoces, defensores y veedores de los derechos de la población civil; acontece en esta reivindicación un desplazamiento de la subjetividad del guerrillero sacrificada por la causa colectiva: "Debemos siempre reflejar nuestra condición de hombres sencillos y dispuestos a dar lo mejor de nosotros por las aspiraciones y anhelos de la población" (Farc-Ep, s.f.). Vezzetti (2009) ha advertido en ello un trasfondo religioso de la política,

una escatología que, en el límite, sitúa sus objetivos fuera de la historia y los encarna en figuras de héroes inalcanzables para los seres humanos de carne y hueso (...). Para que esto suceda es preciso que se implante un complejo de valores $\mathrm{y}$ actitudes en torno de la figura del guerrero, el culto de la acción por la acción, la prepotencia del coraje, la fascinación por las armas, los mitos de la guerra que aplastan la lógica política (p. 202). 
Dentro de esos mitos, el fundacional condensa lo que se espera del guerrillero en imitación de los padres fundadores, modelos que por estar en el origen de un proyecto ahistórico, se inmortalizan de manera simbólica. A esto responde la moral de conducta que explicita Jacobo Arenas (1972) en sus textos dirigidos a los combatientes:

Un soldado de la revolución desmoralizado es algo triste y degradante. Nadie tiene por qué sentir miedo. Es necesario mantener el más perfecto control sobre sí mismo. Si la aviación está ametrallando y las bombas están cayendo por ahí cerca del guerrillero, el combatiente no tiene por qué amilanarse, por qué asustarse. Para eso está debidamente protegido, debidamente atrincherado, para eso conoce el terreno, domina el terreno y sus vías de escape, para eso está a cubierto de la vista del enemigo. Cuando los aviones ametrallan o bombardean, lo están haciendo a tientas, no están apuntando sobre cada uno de nosotros, porque no nos ven.

En este sentido, el ataque a Marquetalia logra exactamente lo contrario de lo que se propone: instaura un hito en la consolidación de un grupo armado, refuerza la percepción del otro como enemigo inhumano en poder de técnicas ilegítimas de fuerza, y endurece la posición del guerrillero a partir del marco de injusticia que se le presenta como evidente. Así, el mito fundacional impacta poderosamente en la construcción de la subjetividad del militante, cabría decir, en el ideal heroico del guerrillero (tabla 1).

Tabla 1. Construcción de la subjetividad del guerrillero fariano

\begin{tabular}{|c|c|c|}
\hline Valor heroico & Modelo en el mito fundacional & Análisis \\
\hline Sencillez & $\begin{array}{l}\text { El conjunto de fundadores, con Manuel Maru- } \\
\text { landa Vélez y Jacobo Arenas a la cabeza, y las } \\
\text { guerrillas comunistas a lo largo de la cordillera } \\
\text { central, compuestas por campesinos. }\end{array}$ & $\begin{array}{l}\text { Se establece una clara oposición con los valores burgueses, asigna- } \\
\text { dos a los terratenientes y al Estado en cabeza del Partido Conser- } \\
\text { vador, tradicionalmente asociado con la oligarquía. Vezzetti (2009, } \\
\text { p. 178) anota como antecedente de esta moral revolucionaria la } \\
\text { tradición jacobina en la Revolución Francesa: "porque habían sido los } \\
\text { pobres y los excluidos quienes, con su sublevación, incluso con sus } \\
\text { terribles masacres, habían abierto el camino al acontecimiento en } \\
\text { tanto expresión de una voluntad general en acto". }\end{array}$ \\
\hline Sacrificio & $\begin{array}{l}\text { Los campesinos combatientes dados de baja } \\
\text { en Marquetalia y la descripción de Jacobo } \\
\text { Arenas sobre las condiciones materiales } \\
\text { paupérrimas con las cuales se inició la lucha } \\
\text { guerrillera. }\end{array}$ & $\begin{array}{l}\text { Desde el concepto mismo de lo heroico, se precisa de la carencia y } \\
\text { la dificultad para llenar de sentido la misión del héroe. Tanto el cami- } \\
\text { no de las pruebas (Campbell, 1998) como la muerte misma purifican } \\
\text { el sino trágico. Desde esta perspectiva, la des-subjetivización del } \\
\text { héroe en función del colectivo y la muerte en batalla son glorificacio- } \\
\text { nes que impulsan a los otros, a través del ejemplo, "a sumarse a la } \\
\text { guerra revolucionaria, cuyo triunfo inminente parece no dejar lugar a } \\
\text { dudas" (Carnovale, 2011, p. 200). }\end{array}$ \\
\hline
\end{tabular}




\begin{tabular}{|c|c|}
\hline Desventaja & $\begin{array}{l}\text { De diferentes tipos: } \\
\text { 1. Numérica: los } 16000 \text { soldados contra los } \\
48 \text { campesinos alzados en armas. } \\
\text { 2. Armamentística: Marulanda (1973) ha seña- } \\
\text { lado que se combatía con fusiles heredados } \\
\text { de la antigua Guerra Civil de los Mil Días } \\
\text { (1899-1902) y que se recuperaban las } \\
\text { armas de los soldados en batalla. } \\
\text { 3. Estratégica: por no contar con apoyo } \\
\text { externo․ } \\
\text { 4. Política: por estar al margen de las leyes he- } \\
\text { chas por los enemigos, a su conveniencia. }\end{array}$ \\
\hline Resistencia & $\begin{array}{l}\text { Contra los excesos de la fuerza pública, los } \\
\text { métodos de guerra anticomunista y la injusticia } \\
\text { social en las relaciones de poder entre cam- } \\
\text { pesinos y terratenientes, todo lo cual lleva a la } \\
\text { continuidad del proyecto insurgente. }\end{array}$ \\
\hline $\begin{array}{l}\text { Colectivismo y } \\
\text { carácter agrario }\end{array}$ & $\begin{array}{l}\text { En el relato, el territorio de Marquetalia es } \\
\text { una zona liberada, donde la tierra pertenece } \\
\text { a quienes la trabajan. Los fundadores se } \\
\text { presentan a sí mismos como representantes } \\
\text { de la comunidad vulnerada, específicamente } \\
\text { del sector campesino. }\end{array}$ \\
\hline $\begin{array}{l}\text { Soberanía / Inde- } \\
\text { pendencia }\end{array}$ & $\begin{array}{l}\text { Los marquetalianos desconocen la política } \\
\text { central del Estado, se rigen bajo sus propias } \\
\text { leyes y orden social, y reclaman para el país } \\
\text { la defensa de la soberanía con respecto a la } \\
\text { injerencia del imperialismo norteamericano. }\end{array}$ \\
\hline
\end{tabular}

Ante lo leído como una agresión militar a una comunidad de campesinos en Marquetalia, la

Combinación de todas las formas de lucha
Hay un carácter épico en la desventaja que, como en la figura de la lucha entre David y Goliat, a la que acudía el Comandante Cano, refuerza una suerte de simpatía por el desaventajado y, al mismo tiempo, antipatía por el opresor. En la teoría del guerrillero, Schmitt

(1963) utiliza ese carácter marginal y minoritario del partisano como una vía hacia la explicación de su figura definitiva, entregada a dicotomías del tipo revolución o muerte:

"El guerrillero moderno no espera ni justicia ni clemencia por parte del enemigo. Se ha apartado de la enemistad convencional de la guerra mitigada y acotada, ingresando en el ámbito de otra enemistad, la verdadera enemistad, que se intensifica mediante el terror y el contra-terror hasta el aniquilamiento".

La resistencia estuvo tempranamente derivada de la naturaleza autodefensiva del movimiento ${ }^{2}$. Si bien posteriormente (1982) las Farc añadirán el carácter de "Ejército del Pueblo", dejando claro que no serán un grupo solo defensivo, el valor de la resistencia seguirá remarcado entre los combatientes y en la postura oficial del grupo (de hecho, la revista virtual que publican periódicamente se denomina así, Resistencia).

El mito fundacional asienta un topos idealizado en las zonas liberadas, a la medida del proyecto comunista, "un mundo ausente de terratenientes y constituido por pequeños propietarios que cultivaban la tierra" (Uribe-Calderón, 2007). Se trata de un proyecto social y económico en franca contradicción con el de los empresarios agrícolas; antagonismo fundamental en la problemática sociopolítica del agro en Colombia.

El reclamo por la injerencia extranjera se asume tanto en la línea política antiimperialista del marxismo-leninismo, como en la inspiración bolivariana que sustenta el proyecto independentista del movimiento, dirigido a la consolidación de una patria libertada de la colonización, ya no territorial, sino simbólica, por las relaciones de dependencia económica, política y militar de Estados Unidos.

La perspectiva maoísta de que "el poder nace del fusil" descartará la deposición de las armas, por enraizarse en el centro mismo de la ideología del grupo y de la convicción del combatiente; un medio -acaso el más obvio o el más terrible, de acuerdo con el mundo interior de cada insurgente- justificado por la nobleza de los fines:

“Cuáles son las formas de lucha? Uno dice, la política, la económica, la ideológica. Dentro de la política aparece la lucha armada, entones, [...] es hacer la política por otros medios" (entrevista al guerrillero Julián Garcés, 1999, en Ferro y Uribe, 2002, p. 145)³.

1 “En Colombia, el movimiento guerrillero nunca dependió de la ayuda externa proveniente del campo socialista u otra nación de este signo ideológico. Esta era marginal" (Pizarro Leongómez, 2004b, p. 171).

2 Este origen señala la relación inicial con las directrices del Partido Comunista Colombiano: la "autodefensa de masas contra la violencia reaccionaria", la "combinación de todas las formas de lucha" y la "transformación de la autodefensa en lucha guerrillera cuando las circunstancias lo hacen necesario". No obstante, es evidente que durante este primer periodo los comunistas no consideraron la lucha armada como el instrumento para acceder al poder. En todos sus documentos se subraya el carácter defensivo de la resistencia armada. Este es el caso, por ejemplo, del XIV Pleno del Comité Central que consideró que la "lucha armada que se ha librado y se libra en algunas regiones, es una expresión heroica de la resistencia de nuestro pueblo contra la represión terrorista de la dictadura y contra la violencia de las bandas reaccionarias" (Pizarro-Leongómez, 1989).

3 Desde el IX Congreso del Partido Comunista, celebrado en 1961, se había aprobado la tesis de la "combinación de todas las formas de lucha revolucionaria". En la resolución política se subrayaba que "la revolución puede avanzar un trecho por la vía pacífica. Pero, si las clases dominantes obligan a ello, por medio de la violencia y la persecución sistemática contra el pueblo, este puede verse obligado a tomar la vía de la lucha armada, como forma principal, aunque no única" (Pizarro-Leongómez, 2004b, p.3). 
Al ser modelados desde el mito fundacional, el carácter universalista de los valores heroicos descritos se conserva y ellos son asumidos como particulares, aterrizados al terreno complejo de la realidad de los actores, para formar parte de la moral del guerrillero; toda vez que instauran 1) identidad, como condiciones de inserción en el grupo, y 2) sentido, como núcleos duros que dotan de contenido y direccionan las luchas; ambos factores construidos, identidad y sentido, ejercen una doble función de cohesión y coerción, es decir, una ortodoxia al mismo tiempo que una deóntica.

Si en la naturaleza del mito fundacional está presente el desangre de los miembros, como en una mecánica implacable, esa misma violencia es instrumentalizada para concebir y aniquilar, para destruir y engendrar: aniquilar y destruir el orden injusto que precede; concebir y engendrar un mundo y un hombre nuevos. Pero

La fórmula marxista termina en verdad alterada en esa visión que reserva a la violencia el papel de progenitora, más que de partera, del devenir. Borrada la preocupación por la diferencia y la relación entre los fines y los medios, la muerte se convierte en un remedio rutinario (Vezzetti, 2009, p. 179).

\section{Conclusiones}

El mito fundacional de las Farc-Ep pervive en el conjunto de valores que definen el perfil de los insurgentes, a través del regreso permanente al relato, recortado desde la visión de los actores y diseminado no solo a través de las fuentes históricas internas del grupo guerrillero, sino también de la constante referencia que se hace sobre él en discursos, artículos y comunicados difundidos a través de los medios masivos.

Los mitos de origen, "como procesos discursivos, condensan elementos tomados de diferentes fuentes, los destilan y, una vez ejecutados ambos procedimientos, proponen derroteros para la acción" (Uribe-Calderón, 2007, p.33), es decir, acusan una función activa dentro de la dinámica insurgente; en esta medida, se dimensionan más allá de la narra- ción y alcanzan funciones pragmáticas. Es a partir del uso que el mito fundacional entra a formar parte de una ideología, toda vez que direcciona los ideales de un grupo, lo mantiene cohesionado y, al mismo tiempo, lo regula desde una moral del guerrillero; identidad y sentido son aquílos componentes principales que se hallan al interior del mito fundacional:

A partir de mecanismos privilegiados de integración, explicación y diferenciación, los mitos pueden articular el pasado con el futuro, llenando de sentido el vacío del presente mediante una sobredeterminación de la memoria. Su eficacia reside en que facultan para actuar a partir de la fuerza de los afectos y de lo que se considera verdadero, sin importar qué definición de la verdad y de la realidad tengan sus adeptos (Uribe-Calderón, 2007, p.33).

En ese sentido, el mito fundacional condensa lo histórico, lo emotivo y lo sociocognitivo, elevando a símbolo el relato del origen, y volviendo a él cada vez que se requiere reforzar, definir o regular la moral del guerrillero.

Ferro y Uribe (2002) encuentran cuatro legados del mito fundacional en la actualidad de las Farc-Ep: 1) su carácter de penetración territorial o de colonización armada; 2) la autonomía organizacional interna e independencia de entidades externas; 3 ) la naturaleza colectiva de la cúpula de poder y su renovación permanente, como fruto de la fundación también colectiva, y 4) el principio de la resistencia como principal factor de cohesión ideológica. En la pregunta por la estabilidad y continuidad del grupo guerrillero, el análisis del mito fundacional permite desplegar estos legados y avizorar otros, como los valores heroicos que forman parte de la moral del guerrillero.

Al transformar un hecho histórico en mito fundacional, la redescripción del hecho en forma de relato institucionalizado le imprime un principio identitario a los orígenes, de manera que la ubicación de un momento histórico establece el inicio de un proceso distinto, valga decir, el inicio de un extenso relato idealizado: el relato de la emancipación de un pueblo a través de la revolución, "un proceso que se inicia con la defensa y la resistencia campesi- 
na, pasa por la propuesta de la revolución agraria y finalmente llega a la plataforma por una revolución nacional" (Ferro y Uribe, 2002, pp. 37-38).

De esta manera, el cerco militar contra Marquetalia es una victoria y una demostración de fuerza legítima, en la versión de ambos actores; para el Estado, es un relato de la capacidad de imposición y superioridad de las fuerzas del orden, mientras que para las Farc es el inicio histórico de una lucha heroica que prevalece. En rigor, los hechos de Marquetalia son un punto de inflexión del conflicto armado colombiano: la reactivación de la guerra de guerrillas y la puesta en escena de dos posiciones combatientes que no han sufrido grandes modificaciones en casi 48 años de confrontación; estas posiciones tienen que ver con una convicción especular sobre la derrota inminente del enemigo, pese a que el correr de los años los contradice frontalmente. Asimismo, con las condiciones de un exterminio abstracto y absoluto, que "no se dirige ya ni siquiera contra un enemigo sino que sirve tan solo a la imposición supuestamente objetiva de valores supremos por los cuales, como se sabe, ningún precio a pagar es demasiado alto" (Schmitt, 1963), así lo corroboran la demonización y deslegitimación del adversario (Sabucedo et al., 2004; Olave, 2011, 2012a), y las pretensiones de anulación del disenso (Olave, 2012b, 2012c, 2012d) en el conflicto armado colombiano. Finalmente, Marquetalia inicia también lo que Pizarro-Leongómez (2004b) ha denominado un círculo vicioso de represalias/contrarrepresalias, basado en la criminalización mutua, que ha desviado el sentido de la oposición política en Colombia.

En una simplificación del problema, sería fácil adherirse a las tesis que acusan a las Farc-Ep de una autopercepción idealizada de sí mismas y de la realidad, a partir de la cual la asimetría (numérica, militar, estratégica y política) haría parte de una ética sacrificial que reforzaría la causa (Ferro y Uribe, 2002), y detrás de la cual se refugiarían para "esconder su imposibilidad de ganar tras la poca posibilidad que tienen de perder" (UribeCalderón, 2007). No obstante, no es la idealización como configuración utópica de la realidad, sino la configuración de una moral y la conceptualización que se hace de los valores que la integran, lo que en gran medida llena de identidad y de sentido la continuidad de las Farc-Ep: su cohesión al mismo tiempo que su coerción.

\section{Referencias bibliográficas}

Alape, A. (1985). La paz, la violencia: testigos de excepción. Bogotá: Planeta.

Arenas, J. (1972). Diario de la resistencia de Marquetalia. Recuperado de: http://www.farc-ep.co/?p=637

Arenas, J. (1985). Cese al fuego: una historia política de las Farc. Bogotá: Oveja Negra. Recuperado de: http://farc-ep.co/wp-content/uploads/2011/libros/ cesefuego.pdf

Campbell, J. (1991). El poder del mito. En diálogo con Bill Moyers. Barcelona: Emecé.

Campbell, J. (1998). El héroe de las mil caras. Psicoanálisis del mito. México: Fondo de Cultura Económica.

Cano, A. (2011, junio 11). Siempre será posible construir escenarios de negociación con el gobierno. Entrevista a Alfonso Cano. Diario Publico.es [En línea]. Recuperado de: http://www.publico.es/internacional/381305/siempre-sera-posible-construirescenarios-de-negociacion-con-el-gobierno

Carnovale, V. (2011). Los combatientes. Historia del PRTERP. Buenos Aires: Siglo XXI Editores.

Centro de Investigación y Educación Popular (CINEP) Programa por la Paz (junio de 2012). Conflicto armado en Colombia durante 2011. Informe especial. Bogotá.

Corporación Nuevo Arco Iris (2012). Política y violencia en 2011: "Las cuentas no son tan alegres". Dinámica de las Farc, Bacrim, ELN y riesgos de la restitución de tierras. Informe anual. Recuperado de: http://www. nuevoarcoiris.org.co/sac/?q=node/1399

FARC-EP (s.f.). Beligerancia. Revista Resistencia. Recuperado de: http://www.abpnoticias.com/boletin_temporal/contenido/libros/Beligerancia_FARC-EP.pdf

FARC-EP (1998). Esbozo histórico. Recuperado de: http:// www.abpnoticias.com/index.php?option $=\mathrm{com}_{-}$ docman\&task $=$ cat_view\&gid $=37 \&$ Itemid $=83$

FARC-EP (2001). Farc, el país que proponemos construir. Bogotá: Oveja Negra.

FARC-EP (2011). Marquetalia, raíces de la resistencia. Recuperado de: http://www.abpnoticias.com/index. php?option=com_docman\&task=cat_view\&gid $=37$ 
FARC-EP (2012, octubre 1). Carta abierta al Comandante Simón Trinidad. Recuperado de: http://farc-ep. $\mathrm{co} / ? \mathrm{p}=1736$

Ferro, J. y Uribe, G. (2002). El orden de la guerra: las FarcEP entre la organización y la política. Bogotá: CEJA.

Hobsbawm, E. (1968). La anatomía de La Violencia en Colombia. En Rebeldes primitivos. Estudio sobre las formas arcaicas de los movimientos sociales en los siglos XIX y XX (pp. 263-273). Barcelona: Ariel.

Jiménez, T. (21 de septiembre de 2012,). Entrevista de Timoleón Jiménez al Semanario Voz. Recuperado de: http://farc-ep.co/?p=1718

Legname, R. (2002). La construcción de los mitos: el mito fundacional en Santiago del Estero. Ciudad Virtual de Antropología y Arqueología. Recuperado de http://www.naya.org.ar/congreso2002/ponencias/ rodolfo_legname.htm

Mackenzie, E. (2007). Las Farc: fracaso de un terrorismo. ¿Hay un hilo conductor entre las agitaciones de 1926 y la matanza de El Nogal en 2003? Bogotá: Debate.

Marulanda, M. (1999). Discurso en la instalación de los diálogos de paz, el 7 de enero de 1999 en San Vicente del Caguán. En: Presidencia de la República, Oficina del Alto Comisionado para la Paz, Hechos de Paz V-VI (p. 265). Bogotá: Presidencia de la República.

Marulanda, M. (1973). Cuadernos de campaña. Texas: Abejon Mono. Recuperado de: http://www.rebelion. org/docs/68099.pdf

Moreno, N. (1967). La moral y la actividad revolucionaria. Secretariado Centroamericano y Centro Internacional de Trotskismo Ortodoxo. Recuperado de http://www.marxists.org/espanol/moreno/ obras/07_nm.htm\#_Toc535146304

Olave, G. (2011). Los marcos del conflicto: aproximación al conflicto armado colombiano desde el concepto de Marco. Revista Discurso \& Sociedad, 5(3), 514-546. Recuperado de: http://www.dissoc.org/ediciones/ v05n03/DS5(3)Olave.html

Olave, G. (2012a). La construcción retórica del conflicto armado colombiano: metafóra y legitimación del carácter bélico del conflicto. Signos 45(80), 300321. Recuperado de http://www.scielo.cl/scielo. php?pid=S0718-09342012000300004\&script $=$ sci_ arttext

Olave, G. (2012b). La construcción retórica del conflicto armado colombiano en el discurso del presidente Juan Manuel Santos. Revista Análisis Político, 76,
159-174. Recuperado de http://www.scielo.org.co/ pdf/anpol/v25n76/v25n76a09.pdf

Olave, G. (2012c). Escenificación y multidestinación en el discurso presidencial de Juan Manuel Santos. Revista ALED, Asociación Latinoamericana de Estudios del Discurso, 12(2), . Recuperado de http://aledportal. com/revistas/12-2/

Olave, G. (2012d). ¿Qué es lo importante? Pregúntele al Presidente. VIII Congreso Internacional de Lingüística Sistémica Funcional, ALSFAL, 27-29 de septiembre. Montevideo, Uruguay.

Pataquiva, G. (2009). Las Farc, su origen y evolución. UNISCI Discussion papers, 19, 154-185.

Pizarro-Leongómez (1989). Los orígenes del movimiento armado comunista en Colombia (1949-1966). Revista Análisis Político, de la Universidad Nacional de Colombia, 7. Biblioteca Virtual Clacso. Recuperado de http://bibliotecavirtual.clacso.org.ar/ar/libros/ colombia/assets/own/analisis\%20politico\%2007.pdf

Pizarro-Leongómez, E. (2004a). Marquetalia: el mito fundacional de las Farc. UNPeriódico, 57, Disponible en: http://historico.unperiodico.unal.edu.co/ Ediciones/57/03.htm

Pizarro-Leongómez (2004b). Una democracia asediada. Balance y perspectivas del conflicto armado en Colombia. Bogotá: Norma.

Rorty, R. (1997). ¿Esperanza o conocimiento? Una introducción al pragmatismo. Buenos Aires: Fondo de Cultura Económica.

Sabucedo, J.; Barreto, I.; Borja, H.; López, W.; Blanco, A.; De la Corte, L. y Durán, M. (2004). Deslegitimación del adversario y violencia política: El caso de las FARC y las AUC en Colombia. Acta Colombiana de Psicología, 12, 69-85.

Salazar, G. (2005). Mirada crítica al conflicto armado colombiano. En: B. Peña. Memorias del SeminarioTaller Internacional de Contextualización sobre Desplazamiento Forzado y Refugio en Zonas de Frontera. Bogotá: Defensoría del Pueblo. Recuperado de: http://www.acnur.org/t3/fileadmin/scripts/doc. php?file=biblioteca/pdf $/ 3825$

Schmitt, C. (1963). Teoría del guerrillero. Observaciones al concepto de Lo político. Editorial Virtual, Recuperado de: http://www.laeditorialvirtual.com.ar/pages/ CarlSchmitt/CarlSchmitt_TeoriaDelPartisano.htm

Tarcus, H. (1998). La secta política. El Rodaballo, V(9), 22-32. 
Universidad Pedagógica Nacional

\section{Facultad de Humanidades}

Uribe-Calderón, M. (2007). Salvo el poder, todo es ilusión. Mitos de origen de los Tigres Tamiles de Sri Lanka (LTTE), las Fuerzas Armadas Revolucionarias de Colombia (Farc) y el Provisional Irish Republican Army de Irlanda del Norte (IRA). Bogotá: Editorial Pontifica Universidad Javeriana.

Valencia, A. (15 de enero de 1999,). La leyenda negra de Marquetalia. Periódico El Tiempo [En línea]. Recuperado de: http://www.eltiempo.com/archivo/ documento/MAM-936843

Vezzetti, H. (2009). Sobre la violencia revolucionaria. Memorias y olvidos. Buenos Aires: Siglo XXI Editores. 